\title{
Defining Internationalization Strategies of Indonesian Universities through Educational Investment Preferences
}

\author{
Inaya Sari Melati ${ }^{1}$, Yulhendri ${ }^{1}$, Hana Netti Purasani ${ }^{2}$ \\ ${ }_{1}^{1}$ Universitas Negeri Semarang, Indonesia \\ 2 Universitas Negeri Padang, Indonesia
}

\begin{tabular}{l}
\hline Article Info \\
\hline Article history: \\
Received: 27 December 2019; \\
Accepted: 24 March 2020; \\
Published: 01 October 2020.
\end{tabular}

Keywords:

Educational Investment; Indonesian Universities; Internationalization; Investment Preference.

\begin{abstract}
The internationalization program for higher education is a promising investment with a valuable return. However, it needs a huge budget. This research aims to analyze investment preferences of 13 internationalization program dimensions in Indonesian universities which aggressively encourage themselves to be a world-class university in the future. The novelty in this research is the usage of investment preference index in determining investment priorities in universities instead of common business entities. The quantitative approach was used by calculating the investment preference index. The research instrument used questionnaire with Likert Scale. Respondents were 190 people including students and lecturers. Based on the investment preference index, the number of international students in undergraduate program had to be the first focus in allocating the money for educational investment, followed by the number of international students in postgraduate program and student exchange program. Meanwhile, international links became the least aspect in educational investment preferences.
\end{abstract}

\begin{abstract}
Abstrak
Program internasionalisasi perguruan tinggi merupakan investasi yang menjanjikan dengan tingkat pengembalian investasi yang besar. Akan tetapi, program ini membutuhkan anggaran yang sangat besar Penelitian ini bertujuan untuk menganalisis preferensi investasi dari 13 dimensi program internasionalisasi di universitas Indonesia yang secara agresive terpacu untuk menjadi universitas bertaraf dunia di masa yang akan datang. Kebaruan dalam penelitian ini adalah penggunaan index preferensi investasi untuk universitas, sedangkan biasanya indeks ini digunakan untuk satuan bisnis biasa. Pendekatan kuantitatif digunakan dengan menghitung indeks preferensi investasi. Instrumen penelitian menggunakan skala Likert. Responden penelitian berupa 190 orang, yang meliputi dosen dan mahasiswa. Berdasarkan indeks preferensi investasi, jumlah mahasiswa asing di program sarjana harus menjadi fokus utama dalam pengalokasian anggaran untuk investasi pendidikan, diikuti dengan jumlah jumlah mahasiswa asing di program pada program pascasarjana dan program pertukaran mahasiswa. Sementara itu, hubungan internasional menjadi aspek terakhir dalam preferensi investasi pendidikan.
\end{abstract}

How to Cite:

Melati, I. S., Yulhendri, Y., \& Purasani, H. N. (2020). Defining Internationalization Strategies of Indonesian Universities through Educational Investment Preferences. Jurnal Pendidikan Ekonomi \& Bisnis, 8(2), 102-110. https://doi.org/10.21009/JPEB.008.1.1 


\section{INTRODUCTION}

Internationalization is the process of integrating an international or intercultural dimension into teaching, research, and service functions of a higher education institution (Knight 2004). Over the past ten years, the issue of internationalization has become increasingly popular among universities. There are two factors that cause internationalization considered important to be adopted in the university framework (Qiang, 2003). The first factor is the demand for globalization which requires that higher education outcomes are able to adapt to all kinds of challenges that occur in global society so that they are able to compete in the international labor market and have adequate economic security to survive amid increasingly fierce competition. The second factor relates to higher education as a social institution as well as a business entity. The recruitment of foreign students has become a significant factor for institutional income and national economic interest. Internationalization is one of the factors that can be "sold" by universities to get higher profits by setting special rates for students who register in international classes. At a macro level, high international student inflows will also be good news in the tourism sector and strengthening the domestic currency.

A myriad of studies that found students' lack of global awareness, multiple-language fluency, and international knowledge of their major disciplines (American Council on Education [ACE], 2000; Hayward \& Siaya, 2001). The same thing happened to Indonesian students. Luthfia (2012) who conducted studies on Indonesian students who continued their postgraduate studies in Australia found that Indonesian students had low self-monitoring. They cannot fulfil the self-monitoring attribute; they cannot control and monitor their behavior to match their knowledge in intercultural communication. Their behavior which is not appropriate for Australian culture is not fully following every word delivered by their interlocutors and some people often whisper in the classroom. In addition, they did not have appropriate self-disclosure. They are not open enough to express themselves and not worthy enough to express it. Often they said "yes" but shown with behavior "no" (ambiguous messages) or with body language that confuse Australians. This attribute cannot be fulfilled due to the cultural background of high-context students who think Australians can catch doubts in their tone of speech when saying "yes" and facial expressions that still don't understand. Whereas Australians come from low-context cultures they are not skilled in "reading" non-verbal messages from people with high-context cultural backgrounds. Their message skills look poor, especially in listening skills. They often seem unable to grasp and understand Australian words. They consider Australians to be very fast-talking and with accents that are difficult to understand. This has an impact on the interaction management of their communication. They cannot develop the topic of conversation well. The attributes of self-monitoring and cultural awareness are also not found in this informal social context. They cannot control themselves not to cut off conversation and listen well when Australians are talking. They also cannot control themselves not to discuss themselves, talk together at one time or make comments that are not needed.

Meanwhile, in terms of work readiness in a cross-cultural work environment, the Indonesian workforce (which is largely higher education output products) also still has problems facing high diversity (Luthfia 2014). Data from the Directorate Controlling of Foreign Worker Utilization (PPTKA) in 2017 recorded that the number of Foreign Workers working in Indonesia in 2017 was 85,974 people. The number of IMTA (Foreign Manpower Utilization permit) issued to long-term and short-term TKA (Foreign Workers) in 2015 was 111,536 people, 2016 was 118,088 people and 2017 was 126,006 people. The largest number came from the PRC, then followed by Japan, South Korea, India, and Malaysia. Foreign workers, who come from outside Asia, mostly are from Australia, USA, England, and France while Indonesian citizens who are abroad reach 4 million people, including as professional workers, students, migrant workers, migrant workers, or permanent residence. With an increasingly high level of cultural diversity, cross-cultural understanding and attitudes are competencies that must be formed at the higher education level so that their output can compete globally.

The insistence on the demand for internationalization programs at higher education causes higher educations in Indonesia to compete as international standard universities with various internationalization programs. The opening of International Classes to facilitate foreign students and domestic students who want to study with an international nuance, student exchange programs, short course scholarships abroad both for students and for lecturers, and other programs are carried 
out to support the university's internationalization vision. This raises prospects and pressures for universities aiming to participate in this international market. Universities need to have a sufficient "international" profile to attract significant foreign students because foreign students will strongly consider the reputation of hotels, tourism and education networks in choosing study programs and countries to continue their studies (Russel 2005). Universities also need adequate infrastructure planning and policy frameworks to manage quality learning growth. These plans can include goal statements, mission statements, vision statements, implementation initiatives, allocated resources, timelines, and performance indicators (Moats-Gallagher 2004; Olson, Green, \& Hill 2006; Paige 2005). All kinds of preparations for internationalization require substantial funding.

However, Indonesian universities are struggling for the funding issues. Indraswari \& Hermawan (2017) stated that funding has become the most challenging aspect in the management level of Indonesian universities, moreover for private universities. An example comes from Universitas Negeri Semarang (UNNES) which was promoted internationalization year in 2018, yet in fact, the funding allocation for students learning facilities (IDR 7.6 billion) were significantly lower than the funding for office administration units (IDR 10.9 billion (UNNES, 2017; UNNES, 2018). The international research publication collaborations decreased from 38 to 17 during 20172018. On the other hand, the number of international student mobility (outbound program) decreased from 350 to 182 students. All of them happened because of insufficient funding in internationalization program. Not only in UNNES, this problem exists on almost every higher education and is the most common barrier encountered in the process of internationalization of higher educations (Green 2007). Therefore investment preferences are needed in allocating limited university resources to realize the internationalization plan periodically, but effectively.

\section{METHOD}

This type of research is quantitative research. This study took samples from 3 major universities in Java and Bali, namely: Universitas Negeri Semarang (Central Java Province), Universitas Singaperbangsa Karawang (West Java Province) and Universitas Pendidikan Nasional (Bali Province). These three universities were chosen because their massive actions in promoting and implementing internationalization programs in their official strategic plan during the past 5 years.

Respondents in this study were 190 people consisting of 174 students and 16 international class management lecturers, including university and faculty leaders. Data collection used an internationalization model questionnaire developed by Elkin, Devjee, and Fransworth (2004). This 13 scale internationalization model used a Likert scale. Each scale ranges from 0 to 10 where 0 is low and 10 is high. The scale is designed to be used twice so that respondents mark two things, namely the current level of internationalization and the desired level of internationalization for their institutions. After the initial analysis, an average percentage of ideal performance and actual performance will be calculated. Respondents who filled out this questionnaire consisted of 3 elements, namely international class managers, including those previously interviewed, 16 people, 78 international class students and 96 regular class students.

The next step is to index investment preferences by arranging thirteen aspects of internationalization based on the highest to lowest expectation value, then multiplied by the gap value or the magnitude of the difference in expectations and reality of each aspect. After that, it will be known the investment preference index of each aspect. The higher the combined value is, the more likely the return on investment is (Elkin, Devjee, \& Fransworth, 2005).

\section{RESULTS AND DISCUSSION}

Based on the data collected from respondents, a calculation for the investment preferences index has counted in this research. The leaders and managers of the internationalization program can base their investment policies on the internationalization program based on the investment preferences index. The higher the combined value is, the more likely the return on investment is (Elkin, Devjee, \& Fransworth, 2005).

Table 1 shows the investment preferences index of internationalization programs at sample three universities in Indonesia based on the highest preference order. 
Table 1. Investment Preference Index for Higher Education Internationalization Programs

\begin{tabular}{|c|c|c|c|c|c|}
\hline Aspect & $\begin{array}{l}\text { Average of } \\
\text { Ideal } \\
\text { Performance }\end{array}$ & $\begin{array}{l}\text { Average of } \\
\text { Current } \\
\text { Performance }\end{array}$ & $\begin{array}{l}\text { Differences } \\
\text { between } \\
\text { ideal and } \\
\text { current } \\
\text { performance }\end{array}$ & $\begin{array}{l}\text { Investment } \\
\text { Preference } \\
\text { Index }\end{array}$ & Rank \\
\hline $\begin{array}{l}\text { The numbers of } \\
\text { international } \\
\text { undergraduate } \\
\text { students }\end{array}$ & 5.76842105 & 3.742105 & 2.026316 & 11.68864 & 1 \\
\hline $\begin{array}{l}\text { International } \\
\text { postgraduate } \\
\text { students }\end{array}$ & 5.7 & 3.663158 & 2.036842 & 11.61 & 2 \\
\hline $\begin{array}{l}\text { Student } \\
\text { exchange } \\
\text { programs }\end{array}$ & 6.22105263 & 4.436842 & 1.784211 & 11.09967 & 3 \\
\hline $\begin{array}{l}\text { International } \\
\text { research } \\
\text { collaboration }\end{array}$ & 5.92105263 & 4.078947 & 1.842105 & 10.9072 & 4 \\
\hline $\begin{array}{l}\text { Staff exchange } \\
\text { programs }\end{array}$ & 5.73684211 & 3.868421 & 1.868421 & 10,71884 & 5 \\
\hline $\begin{array}{l}\text { Overseas } \\
\text { curriculum }\end{array}$ & 5.95263158 & 4.163158 & 1.789474 & 10,65208 & 6 \\
\hline $\begin{array}{l}\text { Support for } \\
\text { international } \\
\text { students }\end{array}$ & 6.17894737 & 4.478947 & 1.7 & 10,50421 & 7 \\
\hline $\begin{array}{l}\text { Attendance to } \\
\text { international } \\
\text { conferences }\end{array}$ & 6.13157895 & 4.436842 & 1.694737 & 10,39141 & 8 \\
\hline $\begin{array}{l}\text { Study program } \\
\text { quality }\end{array}$ & 6.26315789 & 4.626316 & 1.636842 & 10,2518 & 9 \\
\hline $\begin{array}{l}\text { Staff training } \\
\text { programs }\end{array}$ & 5.85263158 & 4.126316 & 1.726316 & 10,10349 & 10 \\
\hline $\begin{array}{l}\text { Internationally } \\
\text { recognized } \\
\text { research activity }\end{array}$ & 6.12105263 & 4.484211 & 1.636842 & 10,0192 & 11 \\
\hline $\begin{array}{l}\text { Staff interaction } \\
\text { in international } \\
\text { context }\end{array}$ & 6.08947368 & 4.484211 & 1.605263 & 9,775208 & 12 \\
\hline $\begin{array}{l}\text { International } \\
\text { links }\end{array}$ & 6.14736842 & 4.573684 & 1.573684 & 9,674017 & 13 \\
\hline
\end{tabular}

Source: data processed, 2019

Based on Table 1, the calculation results of investment preference indexes, investment fund preferences managed by universities are recommended to be used to increase the number of international students in undergraduate programs. Based on the opinion of Elkin, Devjee, \& Fransworth (2005), if the university management makes a program to increase the number of international students in the undergraduate program, then they will get the highest Return on Investment compared to spending investment funds on other aspects of internationalization. This is confirmed by the results of the calculation of investment preferences, that the use of the second largest investment fund is recommended for use in programs to increase the number of international students in postgraduate programs. Thus, it can be concluded that increasing the number of international students in both undergraduate and postgraduate programs is highly recommended to be the focus of university investment activities.

If it is assessed from the financial aspect, the presence of foreign students will indeed be beneficial because they will pay higher tuition fees compared to domestic students. However, Breuning (2007) states that the benefits of international student attendance far exceed the university income 
due to their existence. International diversity can enrich the learning experience and social interaction of domestic students who may not have the opportunity to travel or live abroad, and can enhance intercultural skills (McMurtrie, 2011; Geelhoed, Abe, \& Talbot, 2003).

On the other hand, indirectly the presence of foreign students will encourage study programs where they learn to carry out curriculum development. As a consequence of the growing number of foreign students, study programs are "forced" to adjust their curriculum according to global demands. In other words, the addition of foreign students to a study program will encourage curriculum internationalization. This condition is in line with Guu \& Leee (2019) finding that despite its ideologically motivated nature, internationalization in higher education might not only produces curricular homogeneity but also creates a heterogeneous context of cultures and values. Besides, it may promotes critical understanding of internationalization, globalization, and diversity among students. In addition, international student populations from diverse countries can provide many opportunities for universities to take part in global issues. They can contribute to global academic cooperation and develop international diplomatic relations (Arthur \& Flynn, 2011; Alberts, 2007).

In the sample universities, the number of foreign students registered from year to year is still very volatile. Since 2013 UNNES accepted varied inbound activities of foreign students, however most of the foreign students were not regular students but only take short courses for a maximum period of 6 months. The existence of foreign students at UNNES as a regular student increased after 2017; a total of 13 international classes were officially opened. In 2019, the number of foreign students at UNNES was only 15 students (Karim 2019). Meanwhile, at Universitas Pendidikan Nasional, the number of foreign students fluctuated each year; from 2016 to 2018 the number of foreign students respectively was 24, 19 and 20 people (www.undiknas.ac.id). The last sample university, Universitas Singaperbangsa Karawang, has designed internationalization program, including international class, at their institution for more than 5 years, however they have not got any international student (data from an interview with the Chief of International Class, October 2019).

Based on data at each of the universities is associated with the results of the calculation of investment preferences, it is necessary to allocate more investment funds to increase the number of foreign students in the sample universities. Effective international recruitment practices are dependent on a deep understanding of student mobility patterns and student decision-making processes (Choudaha \& Chang 2012). The study of Choudaha \& Chang found that there were 4 things that were considered by international student enrolment in the US: source countries, destination states, enrolment by academic level, and recruitment practices. Although this research was conducted in the US, the first two factors can be considered quite relevant if universities in Indonesia want to develop strategies to increase the number of foreign student enrolments.

The first factor is source countries. The majority of foreign students enrolled in the sample universities were students from Asian countries (Malaysia, Thailand, and Taiwan) and Islamic countries such as Libya, Tanzania, Khazakstan, Krygistan, and Tajikistan. From this enrolment pattern, it can be formulated that foreign students who decide to study in Indonesia are from neighboring countries on the grounds of proximity to location so as to minimize travel costs and cultural shock. In addition, foreign students who decide to study in Indonesia come from Muslim countries, or are Muslims who want to get more comfort in worship, because Indonesia is a country with the largest Muslim population in the world. Promotion strategies that can be drawn up based on this pattern are focused on promoting university enrolment in Muslim countries and neighboring countries. The second factor is destination states. The country of Indonesia is a very interesting country to visit because it has many exotic tourist attractions. In addition, the cost of living in Indonesia is relatively cheap and the acceptance of local people towards foreigners entering Indonesia is very good. These things become values-added that needs to be highlighted when doing promotions abroad.

Of the various meanings derived from the term 'international', the most important is the shared belief that international education will become a quality education. It is assumed that the quality of teaching in international programs will be higher than local ones. However, circumstances can occur where the expectations of foreign students about the quality of teaching, supervision and care provided by their host institution are not realistic (Harris 1997). There is no reason to assume that this does not happen to foreign students who tend to be unfamiliar with the practice of education at their new 
university. The participants' expectations about the quality of their program are the benchmarks for measuring their experiences. Thus, an honest and realistic promotion of the situation in Indonesian higher educations must be conveyed to prospective foreign students.

A large gap between expectations and reality will worsen the experience of foreign students so that the testimony they will present to their peers in their home country will be bad. This can pose a big risk in the sustainability of the internationalization program. Conversely, if foreign students find that the learning experience in Indonesia is better than their previous estimates, then their testimony will increase the number of foreign students who register in the next school year. It implies that universities as a business entities have to always improve their services by creating innovations to maintain student satisfaction. Kandampully (2002) stated the technology, knowledge and networks are the core competencies of innovation in service business. Universities can use various technologies to improve students' learning activities. Besides, technology can forge university networks to extend their knowledge about internationalization program and to offer higher value not only for international students but also for domestic students.

The third investment preference is on student exchange programs. Several studies have found that student exchange programs influence feelings of social inclusion that play a role in the development of student self-esteem (Back, Krause, et. al. 2009; Denissen et al. 2008). Hutteman, R., Nestler, S., Wagner, J., Egloff, B., \& Back, MD (2015) found that students showed an increase in the country's self-esteem when abroad and simultaneously showed an increase in the perception of social inclusion in the country origin. Students who take part in student exchange programs experience an increase in their ability to conquer challenges faced while the program takes place abroad. These challenges include language differences, cultural differences and differences in work ethics. The ability to adapt to various conditions is very important as a provision for students' mental development to be able to compete not only in the domestic labor market but also in the international labor market. Students who take part in student exchange programs also experience positive changes in their sense of nationalism and experience an increase in feelings of social inclusion. They become more sensitive to the conditions of the people in their country after gaining a lot of experience in socializing in other countries.

The benefits of the student exchange program are significant for the mental development of these students which makes this aspect occupy the third investment preference after the number of foreign students of undergraduate and postgraduate programs. Shieh (2004) finds international exchange programs have several benefits, including each student has a lived experience with a new culture that is distinct from his or her own, encourage a student to become a cultural mediator, bridging cultures to promote international understanding, and leads students to personal growth. Tjoflåt, Razaonandrianina, Karlsen \& Hansen (2017) add dealing with working together issues as one of many merits in joining international student exchange program. Another benefit of this program is stated by Cushner (2012) who finds fostering international mindset through exchange program among leads students to be innovative and to be curricular adaptive (Tudball, 2012).

In the three sample universities in Indonesia, a common obstacle in the student exchange program was funding. There are not many program grants that can be budgeted by institutions. As a consequence, students must actively look for sources of self-financing. The role of the institution in this case is to provide information on the broadest student exchange program to students. More intense socialization can be done to inform the fully-funded student exchange program.

The three highest investment preferences based on the findings of this study can be made as the main focus of funding for the internationalization program before moving on to the other ten aspects. Roger (2003) states that the strategy to innovate and change can be done by creating an "initial innovator" which is then valued for his success, then continued by creating conditions and appreciation for those who spread the adoption of the system for the first time, then building the entire system for majority.

Based on Roger's opinion, there are three important points that can be formulated in order to build a system to support the internationalization program of higher educations in Indonesia. First, the need for a pilot project. In this case the faculty can choose an international class to be used as a pilot class by applying a new internationalization system to the class, and conducting regular evaluations. This pilot project must be followed by providing appropriate incentives for those who have 
worked hard and participated in building and succeeding the new system. The provision of incentives is a form of appreciation that is believed to increase the work ethic of both managers and students who are objects in the pilot program. The granting of incentives is certainly not only material, but also recognition in the form of an Assignment Letter for managers and a Decree for students. Second, giving attention and appreciation to the managers of the internationalization program outside the pilot program if they are willing to follow the pilot system that has been built and successfully demonstrate that the system works well. And third, when the system has been evaluated and perfected, socialization is done in order to achieve a common perception so that the objectives of the internationalization program can be understood and supported by all elements in higher education so that all components can work together in achieving the objectives of the internationalization program.

\section{CONCLUSIONS AND SUGGESTION}

The development of the internationalization plan is very important for the operationalization of the goals of internationalization of higher educations in Indonesia. However, funding is always a major problem faced because the internationalization program requires a lot of funds. Therefore it is necessary to allocate funds to the most appropriate aspects so that the goal of internationalization can be achieved at the most efficient cost. Based on the analysis of investment preferences, it was found that the allocation of investment funds that was expected to produce the greatest return was in the aspect of increasing the number of foreign students both undergraduate and postgraduate programs and increasing the number of students involved in student exchange programs. For this reason, higher education fund allocations should be invested in programs capable of supporting these priority aspects.

\section{REFERENCES}

Alberts, H. C. (2007). Beyond the Headlines: Changing Patterns in International Student Enrollment in the United States. GeoJournal, 68, 141-153, https://doi.org/10.1007/s10708-007-9079-7.

American Council on Education. (2000). ACE Survey of International Attitudes and Knowledge. Washington, DC: American Council on Education.

Arthur, N., \& Flynn, S. (2011). Career Development Influences of international students who Pursue Permanent Immigration to Canada. International Journal of Educational and Vocational Guidance, 11, 221-237, https://doi.org/10.1007/s10775-011-9212-5.

Back, M. D., Krause, S., Hirschmüller, S., Stopfer, J. M., Egloff, B., \& Schmukle, S. C. (2009). Unraveling the Three Faces of Self-Esteem: A New Information-Processing Sociometer Perspective. Journal of Research in Personality, 43, 933-937. doi:10.1016/j.jrp.2009.04.002

Breuning, M. (2007). Undergraduate International Students: A Resource for the Intercultural Education of American Peers? College Student Journal, 41, 1114-1122.

Choudaha, R., \& Chang, L. (2012). Trends in International Student Mobility. World Education News \& Reviews, 25(2), https://ssrn.com/abstract=2184988.

Cuervo-Cazurra, A. (2011). Selecting the Country in Which to Start Internationalization: The NonSequential Internationalization Model. Journal of World Business, 46(4), 426-437, https://doi.org/10.1016/j.jwb.2010.10.003.

Cushner, K. (2012). Intercultural competence for teaching and learning. In B. Shaklee and S. Baily

(Eds.), Internationalizing teacher education in the United States, (pp. 41-58).

Denissen, J. J., Penke, L., Schmitt, D. P., \& van Aken, M. A. (2008). Self-Esteem Reactions to Social Interactions: Evidence for Sociometer Mechanisms across Days, People, and Nations. Journal of Personality and Social Psychology, 95, 181-196. doi:10.1037/0022-3514.95.1.181

Directorate Controlling of Foreign Worker Utilization (PPTKA). (2017). Pelayanan Penggunaan Tenaga Kerja Asing Online. Kementrian Ketenagakerjaan Republik Indonesia. Retrieved from: https://tka-online.kemnaker.go.id/

Elkin, G., Devjee, F., \& Farnsworth, J. (2005). Visualising the "Internationalisation" of Universities. International Journal of Educational Management, 19(4), 318-329, https://doi.org/10.1108/09513540510599644. 
Geelhoed, R. J., Abe, J., \& Talbot, D. M. (2003). A Qualitative Investigation of U.S. Students' Experiences in an International Peer Program. Journal of College Student Development, 44, 517, DOI: $10.1353 / \mathrm{csd} .2003 .0004$.

Green, M. F. (2007). Internationalizing Community Colleges: Barriers and Strategies. New Directions for Community Colleges, 2007(138), 15-24, DOI: 10.1002/cc.

Gu, M. M., \& Lee, J. C. K. (2019). “They lost internationalization in pursuit of internationalization”: students' language practices and identity construction in a cross-disciplinary EMI program in a university in China. Higher Education, 78(3), 389-405.doi: https://doi.org/10.1007/s10734-018$\underline{0342-2}$

Harris, R. (1997) Overseas Students in the United Kingdom University System: a Perspective from Social Work, in: D. McNamara \& R. Harris (Eds) Overseas Students in Higher Education. Issues in Teaching and Learning (London, Routledge).

Hutteman, R., Nestler, S., Wagner, J., Egloff, B., \& Back, M. D. (2015). Wherever I May Roam: Processes of Self-Esteem Development from Adolescence to Emerging Adulthood in the Context of International Student Exchange. Journal of Personality and Social Psychology, 108(5), 767, http://dx.doi.org/10.1037/pspp0000015.

Indraswari, R., \& Hermawan, Y. P. (2017). Nation Branding Indonesia: Internasionalisasi Pendidikan Tinggi sebagai Upaya Peningkatan Soft Power Indonesia. Laporan Penelitian. Universitas Katolik Parahyangan. Bandung.

Kandampully, J. (2002). Innovation as the core competency of a service organisation: the role of technology, knowledge and networks. European Journal of Innovation Management, 5(1), 1826. doi:10.1108/14601060210415144

Karim, M. (2019). Open for International Classes, UNNES Ready to Compete at the Global Level. Retrieved from http://io.unnes.ac.id/p=282.

Knight, J. (1994). Internationalization: Elements and Checkpoints. CBIE Research No. 7. Canadian Bureau for International Education (CBIE)/Bureau canadien de l'éducation internationale (BCEI). 220 Laurier Avenue West, Suite 1550, Ottawa, Ontario K1P $5 Z 9$.

Luthfia, A. (2012). Realitas Kompetensi Komunikasi Antar Budaya pada Proses Adaptasi Pelajar Indonesia di Luar Negeri. Humaniora, 3(2), 558-565, https://doi.org/10.21512/humaniora.v3i2.3399.

Luthfia, A. (2014). Pentingnya Kesadaran Antarbudaya dan Kompetensi Komunikasi Antarbudaya dalam Dunia Kerja Global. Humaniora, 5(1), 9-22, https://doi.org/10.21512/humaniora.v5i1.2976.

McMurtrie, B. (2011, November). International Enrollments at U.S. Colleges Grow but Still Rely on China. The Chronicle of Higher Education. Retrieved from http://chronicle.com/article/International-Enrollments-at/129747/

Moats-Gallagher, C. (2004). Leading the Internationalization of Land Grant Institutions: Crafting a Strategic Approach. Retrieved January, 6, 2006.

Olson, C. L., Green, M. F., \& Hill, B. A. (2006). A Handbook for Advancing Comprehensive Internationalization:What Institutions Can Do and What Students Should Learn. Washington, DC: American Council on Education. Paige, R. M. (2005). Internationalization of Higher Education: Performance Assessment and Indicators.Nagoya Journal of Higher Education, 5, 99-122.

Qiang, Z. (2003). Internationalization of Higher Education: Towards a Conceptual Framework. Policy futures in education, 1(2), 248-270, https://doi.org/10.2304/pfie.2003.1.2.5

Rogers, Everett M. 2003. Diffusion of Innovations. New York: Free Press.

Russell, M. (2005). Marketing Education: A Review of Service Quality Perceptions among International Students. International Journal of Contemporary Hospitality Management, 17(1), 65-77, https://doi.org/10.1108/09596110510577680.

Shieh, C. (2004). International Exchange Program: Findings from Taiwanese Graduate Nursing Students. Journal of Professional Nursing, 20(1), 33-39. doi:10.1016/j.profnurs.2003.12.003 
Siaya, L., \& Hayward, F. (2001). Public experience, attitudes, and knowledge: A Report on Two National Surveys about International Education. Washington, DC: American Council on Education.

Tjoflåt, I., Razaonandrianina, J., Karlsen, B., \& Hansen, B. S. (2017). Complementary knowledge sharing: Experiences of nursing students participating in an educational exchange program between Madagascar and Norway. Nurse Education Today, 49, 3338. doi:10.1016/j.nedt.2016.11.011

Tudball, L. (2012). Global perspectives on the internationalization of teacher education: Through an Australian lens. In B. Shaklee and S. Baily (Eds.), Internationalizing teacher education in the United States, (pp. 93-112). Lanham: MD: Rowman \& Littlefield Publishing

Undiknas. (2018). Profile Universitas Pendidikan Nasional (Undiknas), Global, Smart, Digital. Resource Document: http://www.undiknas.ac.id/

UNNES. (2018). Laporan Tahunan Rektor. Internasionalisasi UNNES Merekat NKRI. Dies Natalis ke-53. Semarang: UNNES. Retrieved from https://unnes.ac.id/ppid/laporan-tahunan-rektor/

UNNES. (2019). Laporan Tahunan Rektor. Mendunia untuk Indonesia. Dies Natalis ke-54. Semarang: UNNES. Retrieved from https://unnes.ac.id/ppid/laporan-tahunan-rektor/ 